\title{
Primary diffuse large B-cell lymphoma or lymphomatoid granulomatosis grade 3: a still-puzzling diagnosis in autopsy
}

\author{
Fernando Peixoto Ferraz de Camposa ${ }^{a}$, Aloísio Felipe-Silvab, \\ Maria Claudia Nogueira Zerbinic, João Augusto dos Santos Martines ${ }^{d}$
}

Campos FPF, Felipe-Silva A, Zerbini MCN, Martines JAS. Primary diffuse large B-cell lymphoma or lymphomatoid granulomatosis grade 3: a still-puzzling diagnosis in autopsy. Autopsy Case Rep [Internet]. 2013; 3(4): 29-36. http:// dx.doi.org/10.4322/acr.2013.036

\section{ABSTRACT}

Primary lung lymphoma is a rare entity accounting for approximately $0.3 \%$ of all primary neoplasia of the lung and includes diffuse large B-cell lymphoma (DLBL) and lymphomatoid granulomatosis (LYG). Considering that clinical features may be similar, whereas epidemiology, morphology, and radiological features are different, the authors report a case of a middle-aged man who presented multiple pulmonary nodules in the lower lobes and groundglass opacities scattered bilaterally on computed tomography. Clinically, he presented a consumptive syndrome with respiratory failure and pleurisy, which progressed until death. The autopsy findings were consistent with lymphomatoid granulomatosis (LYG) grade 3/ diffuse large B-cell lymphoma (DLBL). The authors call attention to the difficulty of establishing an accurate diagnosis, mainly when the demonstration of EBV-infected atypical B-cells fails.

Keywords: Lung; Lymphoproliferative Disorders; Respiratory Insufficiency; Autopsy.

\section{CASE REPORT}

A63-year-old male patient was reportedly well until the unintentional $13 \mathrm{~kg}$ of weight loss occurred over the past 3 months, concomitantly presenting dyspnea, dry cough, ventilatory-dependent thoracic pain, hiporexia, but no fever. He was admitted to a medical facility where a thoracocentesis and a pleural biopsy were performed. Pleural fluid was an exudate with lymphomononuclear cellularity predominance and the histologic examination of the pleural biopsy showed inflammatory infiltrate.
Physical examination at admission revealed an ill-looking patient, cachectic, pale, tachypneic with room air oximetry of $82 \%$. He was afebrile and hemodynamic parameters were within normal limits. Clubbed fingers were present. Neurological and cardiac examinations were normal, and no pathologic peripheral adenomegaly was observed. Thoracic examination revealed the presence of pleural effusion along with diffuse wheezing and rales. Cardiac and abdominal examination was unremarkable. Blood gas analysis showed

\footnotetext{
a Department of Internal Medicine - Hospital Universitário - Universidade de São Paulo, São Paulo/SP - Brazil.

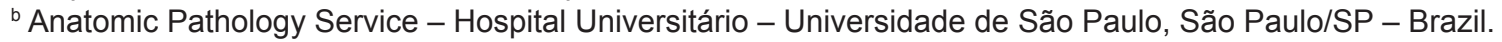

c Department of Pathology - Faculdade de Medicina - Universidade de São Paulo, São Paulo/SP - Brazil.

d Diagnostic Imaging Service - Hospital Universitário - Universidade de São Paulo, São Paulo/SP - Brazil.
}

Copyright $\odot 2013$ Autopsy and Case Reports - This is an Open Access article distributed of terms of the Creative Commons Attribution NonCommercial License (http://creativecommons.org/licenses/by/3.0/) which permits unrestricted non-commercial use, distribution, and reproduction in any medium provided article is properly cited. 
hypoxemia with hypocapnia. Serologies for HIV were negative; and Epstein-Barr virus (EBV) and cytomegalovirus (CMV) were positive for IgG but negative for IgM.

The thoracic computed tomography (CT) showed the presence of an infiltrative mass with soft-tissue attenuation involving the posterior mediastinum, the chest wall and the pleura, which was associated with pleural effusion and atelectasis of the left lower lobe. The descending aorta and its branches were involved by the mass, but neither vascular invasion nor bone erosion were observed (Figure 1A).

In the right lower and middle lobes, diffuse ground-glass opacity and irregular nodules were observed (Figure 1B), as well as smaller nodules present in the left lung. The upper lobes exhibited bullae and pan-lobular emphysema.

The patient was initially prescribed ceftriaxone and clarithromycin, non-invasive ventilatory support, and physiotherapy. Since the clinical picture did not improve, the antibiotics were empirically changed to meropenem. Unfortunately, marked impaired clinical status prevented further diagnostic work-up. Respiratory insufficiency worsened and the patient died after 8 days of hospitalization.

\section{AUTOPSY FINDINGS}

The ectoscopy revealed a very emaciated cadaver with clubbed fingers. At the opening of the left thoracic cavity, a huge amount of whitish pleural effusion was drained while some fluid was kept enclosed within pleural adhesions. A whitish pleural thickening extended into the interlobular septa, in the lung (Figure 2A). This tissue infiltration involved almost the entire thoracic aorta (Figure 2B), the parietal pericardium, the mediastinum, and the diaphragm to some extent. The lungs were congested and heavy, due to marked edema and congestion. The left lung weighed $871 \mathrm{~g}$ and the right lung $975 \mathrm{~g}$ (reference value, (RV): $375 \mathrm{~g}$ and $450 \mathrm{~g}$, respectively). The superior lobes showed anthracosis and cystic emphysema, which was also present and scattered bilaterally through the remaining lobes. Pulmonary thromboemboli were detected in the segmental and subsegmental branches of the left inferior lobe. The right hemithorax showed serosanguineous pleural effusion. The heart was enlarged, which was mainly due to left ventricular wall hypertrophy (heart weight was 400 g; RV: $276 \mathrm{~g})$. The left ventricular apex exhibited a mural thrombus, and atherosclerosis was mild in the coronaries, while the aorta was markedly involved with calcifications. Pulmonary whitish and firm non-necrotic nodules measuring up to $3 \mathrm{~cm}$ were noted in the right inferior lobe and diaphragmatic lung surface; some of them merged with the pleural thickening (Figure $3 \mathrm{~A}$ ). Subcarinal anthracotic and reactive enlarged lymph nodes were present.
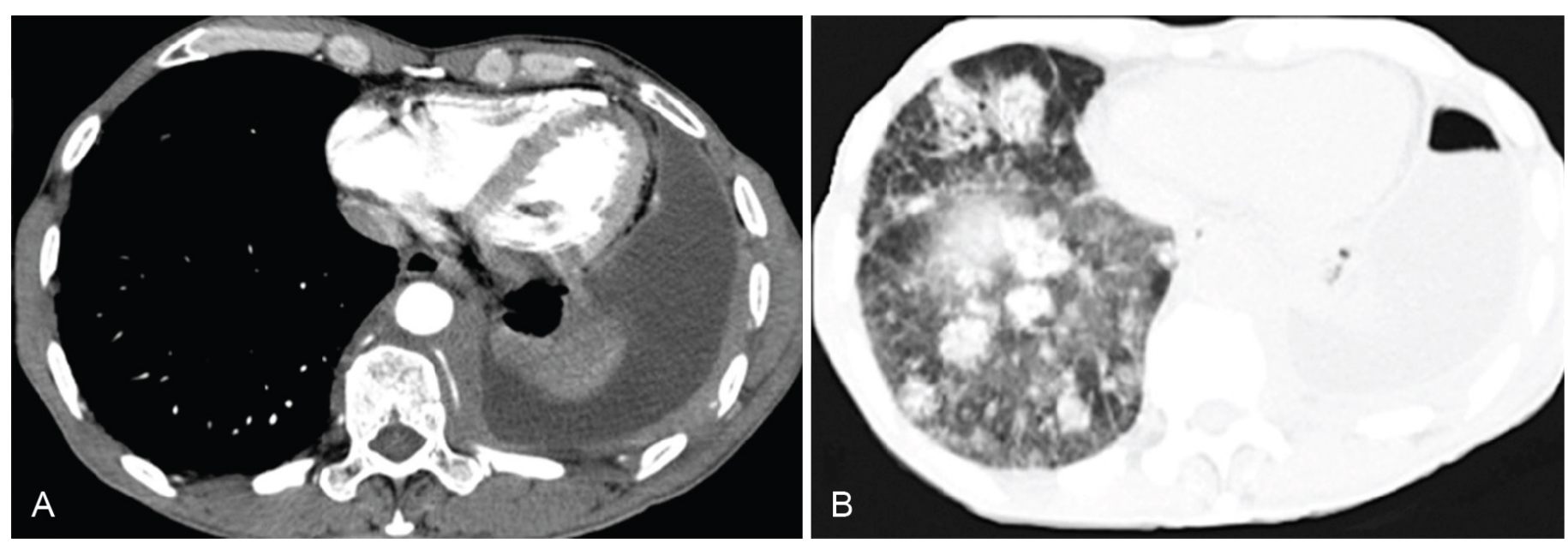

Figure 1 - Axial CT of the thorax - A - mediastinum window showing retraction of the base of the left hemithorax. Infiltrative homogeneous mass with soft-tissue attenuation involving the chest wall, pleura, and posterior mediastinum, can be seen, which is associated with pleural effusion and atelectasis of the left lower lobe. Note the involvement of the descending aorta and branches without vascular invasion or bone erosion; B - pulmonary window showing multiple solid pulmonary nodules at the right lung base, some of which exhibit air bronchogram. 

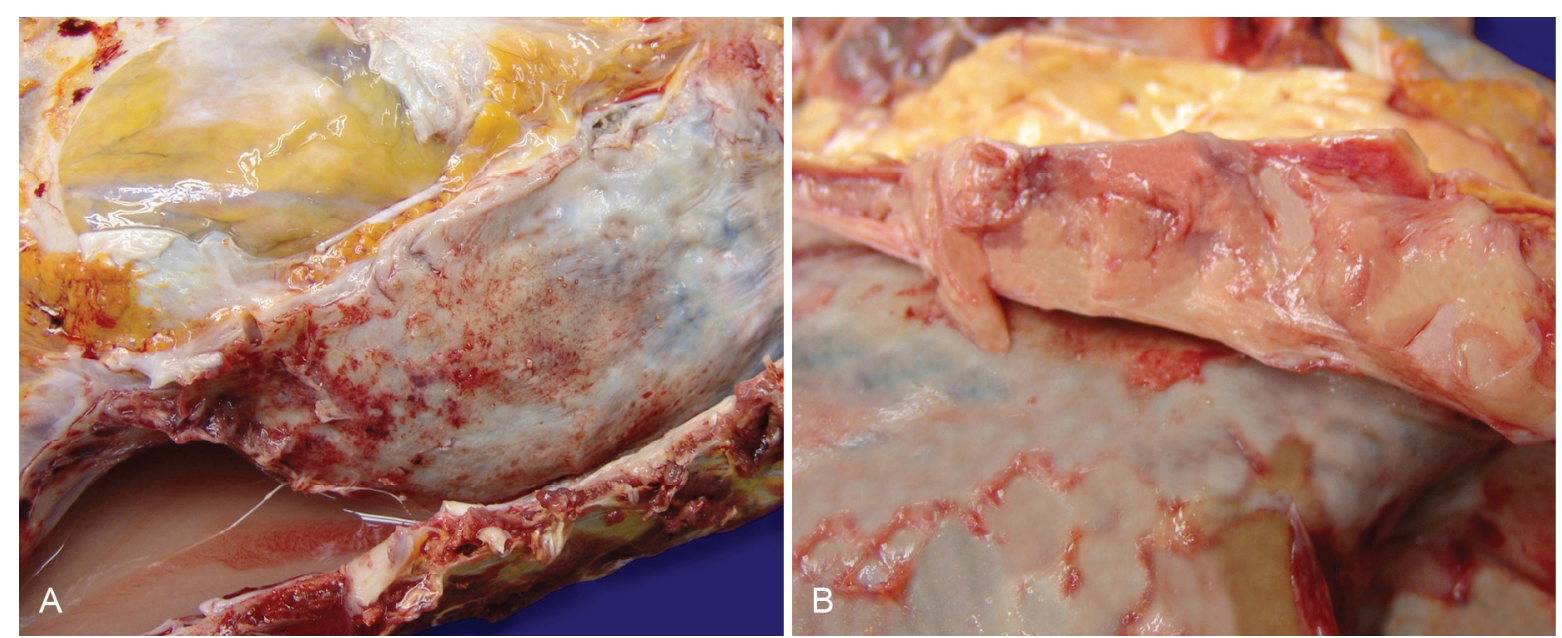

Figure 2 - A - Gross aspect of the left pleural surface and whitish pleural fluid (bottom). B - "Fish flesh" gross aspect of the tumor involving the thoracic aorta.
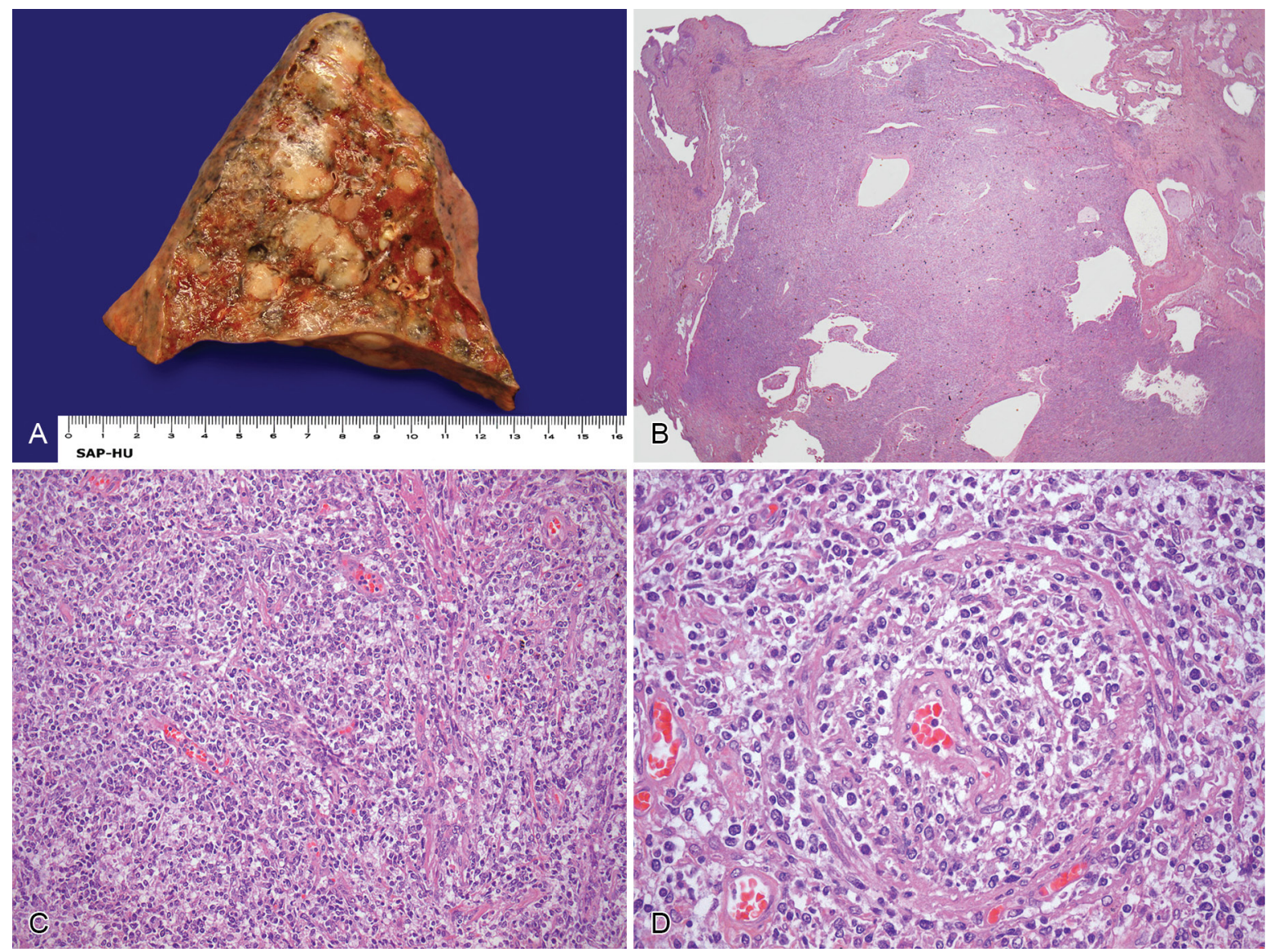

Figure 3-A - Gross aspect of the right lung showing sharply circumscribed nodules; $\mathbf{B}$ - Photomicrography of a nodular lesion (HE, 100X); C - Diffuse aspect of lymphoid proliferation in sheets with inflammatory background (HE, 200X); D - Perivascular destructive infiltration (angiocentrism) (HE, 400X).

The histologic findings of the pulmonary nodules (Figure 3B), infiltrative pleural lesion, posterior mediastinum, and periaortic involvement were characterized by a proliferation of atypical B-lymphocytes (Figure 3C), sometimes in a sheet-like and angiocentric perivascular pattern (Figure 3D). These cells were immersed in a diffuse background of numerous small T-lymphocytes, histiocytes, and occasional plasma cells, with moderate angiocentric behavior but no central necrosis. Immunohistochemistry profile of atypical large cells was $\mathrm{CD}^{2} 0^{+}$(Figure 4A); PAX5+; CD30-. The proliferation index, accessed by Ki67, was approximately $90 \%$. Small background lymphocytes were mostly CD8 ${ }^{+}$(Figure 4B). EBV was negative by both in-situ hybridization, and immunohistochemistry gave a negative result. These findings were consistent with a pleuropulmonary diffuse large B cell lymphoma (DLBL) with some features reminiscent of grade 3 lymphomatoid granulomatosis (LYG). The 

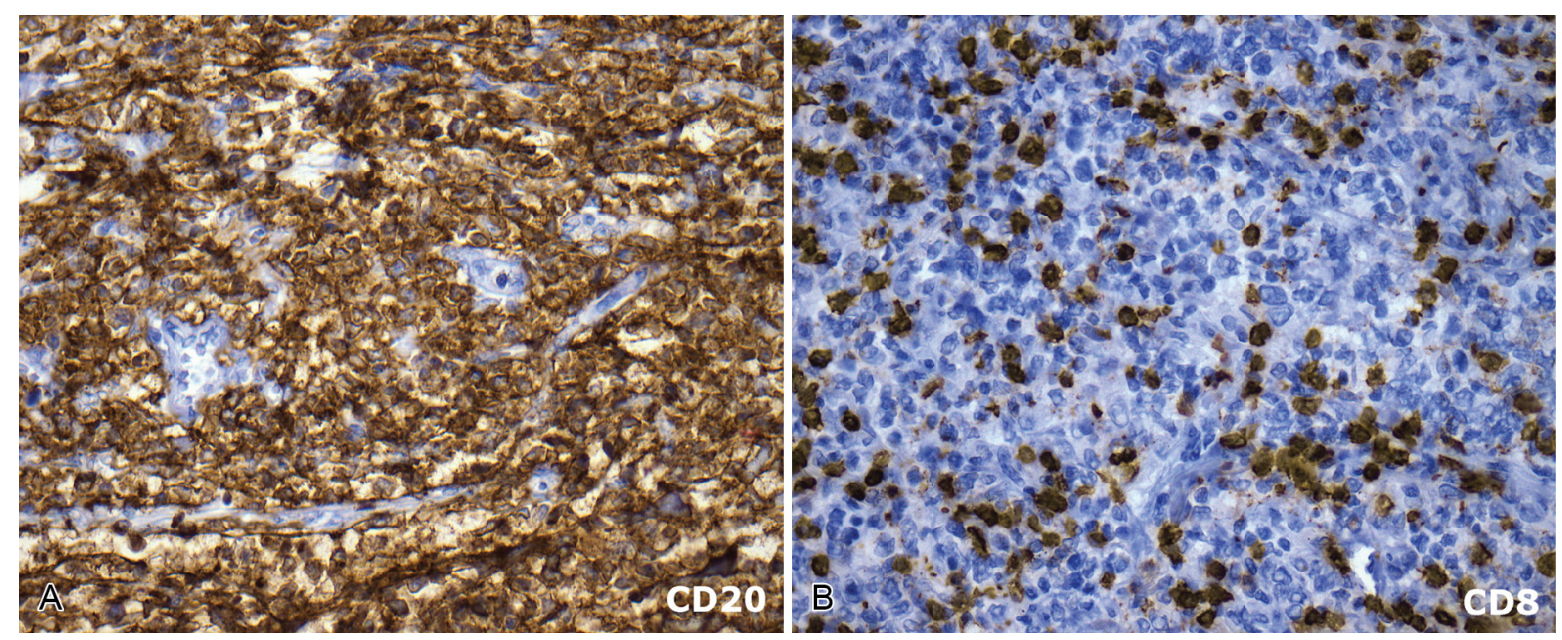

Figure 4 - Immunohistochemistry (400X) showing diffuse CD20 staining (A), in a background of reactive CD8+ T-lymphocytes (B), and histiocytes.

mediastinal and abdominal lymph nodes, spleen, liver, and bone marrow were free of neoplasia.

Other pulmonary findings were diffuse alveolar damage (acute and organizing), organizing pneumonia, interstitial fibrosis, anthracosis, and respiratory bronchiolitis. Ferruginous bodies and other evidence of asbestos exposure were not detected.

Other autopsy findings included acute tubular necrosis and signs of systemic hypertension.

\section{DISCUSSION}

The lymphoid tissue of the lung is represented by sparse submucosal aggregates of small lymphocytes, which become more pronounced along the bronchioles and central airways and the intraparenchymal, septal, and hilar lymph nodes. ${ }^{1}$ Various antigenic stimuli trigger an immune response, which leads to lymphoid hyperplasiaoften referred to mucosa-associated lymphoid tissue (MALT) or malignant lymphoproliferative disorders. ${ }^{2}$

Extranodal non-Hodgkin lymphomas have been reported to occur in any organ of the body, but the lung is one of the most common sites, following the gastrointestinal tract, skin, and nervous system. ${ }^{3,4}$ The so-called primary lung lymphomas (PLLs) are rare, hence the lungs are involved by lymphomas mostly secondarily through hematogenous dissemination of Hodgkin or nonHodgkin lymphomas, or by contiguous invasion from a hilar or mediastinal site. ${ }^{3}$ PLLs represent only $0.3 \%$ of all primary malignancies of the lung, less than $1 \%$ of all cases of non-Hodgkin lymphoma, and $3-4 \%$ of all the extra nodal manifestations of non-Hodgkin lymphomas. ${ }^{3,5,6}$

The most common PLLs are of B-cell lineage and include the marginal zone lymphoma (MZL), which is the most common and accounts for approximately $70 \%$ of cases, ${ }^{7}$ followed by the primary pulmonary DLBL, which accounts for 12$20 \%$ of cases. ${ }^{8-11}$

Primary DLBL of the lung occurs mostly during the sixth or seventh decades of life and presents usually symptomatic with dyspnea, cough, and severe impairment of the general clinical status. Although this lymphoma is more frequently associated with HIV infection, it has also been identified in non-immunosuppressed patients, which does not show any clinical difference with the former. A subset of lymphomas arises by transformation of pre-existing or concurrent MZL, small lymphocytic lymphoma, and follicular lymphoma. ${ }^{12}$ Boone et al. ${ }^{13}$ reported the case of a DLBL following the treatment of a grade 3 LYG. A newly recognized subset of this lymphoma is the aggressive EBV-DLBL of the elderly, which arises in patients older than 50 years, (mean age of 72 years, with $25 \%$ of cases occurring in patients older than 90 years), although rare cases have been described in younger patients. In this subset of DLBCL, pleural effusions have been noted in $9 \%$ of cases where atypical cells CD20 (EBV RNA $\left(\mathrm{EBER}^{+}\right)$) over $\mathrm{CD}^{+}$background cells are evident in cell-block preparations. ${ }^{14}$ Radiological findings of this lung lymphoma show that, in general, it constitutes a solitary pulmonary mass accompanied by loco regional invasion, although ground-glass shadows are also reported. Eventually, pleural effusion may also be present. ${ }^{15-17}$ 
LYG is a rare pulmonary disease (less than $3 \%$ of all PLLs) with a high mortality rate, which was first described by Liebow et al. ${ }^{18}$ in 1972 . They questioned whether it was part of an inflammatory process or a lymphoproliferative disorder. As time passed, LYG was accepted as a lymphoproliferative disease, although some other uncertainties still remain.

LYG is more common among middle-aged adults with a mean age of $48-50$ years (range 40-70 years) with male predominance (male to female 2:1). Fever, cough, dyspnea, chest pain, malaise, and weight loss are the most common presenting complaints. ${ }^{19}$ Eventually, hemoptysis may be present. Clinical features may also reflect a multiorgan systemic disease, because, in addition to pulmonary involvement, the skin, brain, kidneys, and liver may be affected independently or concurrently in the late course of illness. ${ }^{2,19}$

The characteristic histology of LYG is represented by nodular replacement of the lung parenchyma by a mixed mononuclear cell infiltrate composed of small lymphocytes $\mathrm{CD}^{+}$ (and characteristics of cytotoxic T-lymphocytes expressing CD8, TIA, and granzyme B), ${ }^{20}$ large lymphocytes $\mathrm{CD}_{20}{ }^{+}$with atypia, histiocytes, and occasional plasma cells. In general, the small lymphocytes predominate, but in some cases the large atypical cells comprise the main cellular component. These large cells may resemble immunoblasts with one or two atypical nuclei, often congregating in small nests or larger aggregates, and frequently around vessel walls. These nodules may contain areas of necrosis, which vary from extensive central areas to small fibrinoid foci. The intima and media are affected, and appear thickened, and are associated with luminal narrowing. No vessel necrosis is observed. This pattern is described as an "angiocentric process," although the blood vessels are secondarily engulfed by the spreading infiltrate, which randomly affects lung parenchyma., ${ }^{2,19}$ The possible role of EBV in the pathogenesis of LYG was raised in 1990 by Katzenstein and Peiper, ${ }^{21}$ and subsequently confirmed in several studies. Since then, the presence of EBV-positive cells by in-situ hybridization (ISH) with EBER is now definitional for LYG. However, EBV positivity ranges from $57 \%$ to $100 \%$ of cases, ${ }^{19,22-25}$ and by immunohistochemical staining for latent protein 1 and EBV nuclear antigen 2 in some cases where ISH was positive for EBER. ${ }^{19,24}$ Because of this, in the absence of EBVpositive cells, the diagnosis should be made with caution. ${ }^{26}$ Beyond the EBV-positive cells, another requirement for LYG diagnosis is the presence of a polymorphous background, without which the WHO classifies it as a DLBL. ${ }^{26,27}$ Evidence of EBV infection may vary in different biopsy sites of the same case, and if the results are negative, they may become positive in subsequent biopsies. In the experience of Katzenstein et al., ${ }^{19}$ staining may be focally positive, and some blocks from the same biopsy specimen may be EBV-negative; whereas others are positive, requiring the testing of multiple blocks to avoid falsenegative results. Diverse opinions remain as if LYG constitutes a specific entity due to its histological heterogeneity. In this setting, maybe considering LYG as an entity with different morphological faces could be more accurate. ${ }^{26}$

Since the Katzenstein et al. ${ }^{28}$ early study in 1979, it was observed that the percentage of atypical large B-cells was directly related to mortality. Therefore, a grading system from 1 to 3 was proposed. Nevertheless, grading is not that easy; it requires the analysis of multiple slides, once the infiltrate appearance varies from area to area on the same slide and among different slides. In 2008, the $\mathrm{WHO}^{27}$ adopted a grading system based on the quantity of large B-cells and the number staining for EBV by ISH. However, Katzenstein et al. ${ }^{19}$ experience in 2010 suggested that counting the number of EBV+ cells may not correlate with the grade, but the proportion of large B-cells in the infiltrate seemed to be more accurate.

Typical imaging findings include: multiple, bilateral, peribronchovascular nodules or masses with well- or poorly-defined margins, ranging from $0.5 \mathrm{~cm}$ to $10 \mathrm{~cm}$ distributed predominantly in the lung bases. ${ }^{2,15,29,30}$ Internal air-bronchogram can be seen, ${ }^{30,31}$ and the nodule may excavate, disappear, or migrate, which is similar to the behavior found in polyangiitis with granulomatosis. Solitary nodules, alveolar, and reticulonodular opacities may occur, but less frequently. Mediastinal lymphadenomegaly is found in $25 \%$ of cases, ${ }^{15,30,32}$ and pleural effusions have been reported in $33 \%$ of cases. ${ }^{28}$ Groundglass opacities accompanied by signs of pulmonary fibrosis $^{15}$ as well as pericardial effusion with epicardial mass has already been described. ${ }^{33}$

Unfortunately, not all cases of LYG present all histologic features recommended for diagnosis, so they require complementation with clinical and radiological data. For this reason Katzenstein et al. ${ }^{19}$ proposed an algorithm and the following criteria (Table 1). 
Table 1 - Criteria for diagnosis ${ }^{19}$

\section{Findings necessary for diagnosis-always present}

1. A mixed mononuclear cell infiltrate containing large and small lymphoid cells often along with plasma cells and histiocytes, which replaces lung parenchyma in a nodular manner, and infiltrates blood vessel walls.

2. Variable numbers of CD20+ large B-lymphocytes, often with cytologic atypia, present within a background of CD3+ small T-lymphocytes.

Findings supporting the diagnosis-usually, but not always, present

3. Necrosis within the cellular infiltrate

4. Positive ISH for EBER

5. Multiple lung nodules show up radiographically, or skin or nervous system involvement

Treatment is widely variable and depends on the LYG grade. Although reports on spontaneous regression have been reported ${ }^{34}$, the modalities combination of corticosteroids, antiviral therapy, and $\alpha$-interferon have been used with minor grades. ${ }^{35,36}$ Prognosis is extremely poor in grade 3 , particularly after a relapse with curative expectation. Meanwhile, in view of the CD20 expression of tumor cells, rituximab has been used either as monotherapy ${ }^{37}$ or in association with chemotherapy. ${ }^{38} \mathrm{~A}$ European Group for Blood and Marrow Transplantation survey identified 6 patients in 10 as disease-free after bone marrow transplantation in a median follow-up of 5.1 years. ${ }^{39}$ Therefore, the differentiation between LYG and DLBL in our case would not be fundamental for treatment purposes.

According to more stringent diagnostic criteria by the $\mathrm{WHO}$ in $2008,{ }^{27}$ the present case should be classified as DLBCL, especially due to the lack of a demonstrable EBV role. However, if one uses broader clinicopathological criteria (Table 1) this case can be seen as a grade 3 LYG. In our view, this case has more features (clinical, radiological, and morphological) in favor of the diagnosis of LYG, despite the negative result of ISH for EBV. For practical purposes, and respecting the recommended caution, the diagnosis of DLBL was made, along with a comment that this could represent an advanced spectrum of LYG. In fact, a diagnosis of lymphoma is recommended in grades 2 and 3 LYG. ${ }^{19}$

This case illustrates the hardship in diagnosing a histologically advanced grade LYG and DLBL, which suggests an overlap of these two entities, as well as the difficulty in reaching this diagnosis in a critically ill patient. It is important to emphasize that clinically the distinction in the advanced stage of the disease makes no difference, as these patients need to be treated as lymphoma.

\section{REFERENCES}

1. Colby TV, Yousem SA. Pulmonary histology for the surgical pathologist. Am J Surg Pathol.1988;12:223-9. http://dx.doi. org/10.1097/00000478-198803000-00008

2. William J, Variakojis D, Yeldandi A, Raparia K. Lymphoproliferative Neoplasms of the Lung. A Review. Arch Pathol Lab Med. 2013;137:382-91. PMid:23451749. http://dx.doi.org/10.5858/arpa.2012-0202-RA

3. Burke JS. Are there site-specific differences among MALT Iymphomas - morphologic, clinical? Am J Clin Pathol.1999;111:S133-43. PMid:9894478.

4. L'Hoste RJ Jr, Fillipa DA, Lieberman PH, Bretsky S. Primary pulmonary lymphomas. A clinicopathologic analysis of 36 cases. Cancer.1984;54:1397-406. http:// dx.doi.org/10.1002/1097-0142(19841001)54:7<1397::AIDCNCR2820540728>3.0.CO;2-4

5. Cadranel J, Wislez M, Antoine M. Primary pulmonary lymphoma. Eur Respir J. 2002;20:750-62. http://dx.doi.org $/ 10.1183 / 09031936.02 .00404102$

6. Rush WL, Andriko JA, Taubenberger JK, et al. Primary anaplastic large cell lymphoma of the lung: a clinicopathologic study of five patients. Mod Pathol. 2000;13:1285-92. PMid:11144924. http://dx.doi.org/10.1038/modpathol.3880235

7. Graham BB, Mathisen DJ, Mark EJ, Takvorian RW. Primary pulmonary lymphoma. Ann Thorac Surg. 200- 5;80:1248-53.

8. Ferraro P, Trastek VF, Adlakha H, Deschamps C, Allen MS, Pairolero PC. Primary non-Hodgkin's lymphoma of the lung. Ann Thorac Surg. 2000;69:993-7. http://dx.doi.org/10.1016/ S0003-4975(99)01535-0

9. Kim JH, Lee SH, Park J, et al. Primary pulmonary nonHodgkin's Iymphoma. Jpn J Clin Oncol. 2004;34:510-4. http://dx.doi.org/10.1093/jjco/hyh095

10. Cordier JF, Chailleux E, Lauque D, et al. Primary pulmonary lymphomas: a clinical study of 70 cases in nonimmunocompromised patients. Chest. 1993;103:201-8. http://dx.doi.org/10.1378/chest.103.1.201 
11. Li G, Hansmann ML, Zwingers T, Lennert K. Primary lymphomas of the lung: morphological, immunohistochemical and clinical features. Histopathology. 1990;16:519-31. http:// dx.doi.org/10.1111/j.1365-2559.1990.tb01157.x

12. Neri N, Jesus Nambo M, Aviles A. Diffuse large B-cell lymphoma primary of lung. Hematology. 2011;16:1102. PMid:21418743. http://dx.doi.org/10.1179/10245331 1X12940641877722

13. Boone JM, Zhang D, Fan F. Lymphomatoid Granulomatosis: a case report with unique clinical and histopathologic features. Ann Clin Lab Sci. 2013;43:181-5. PMid:23694794.

14. Rooper L, Gocke CD, Belchis DA. Pleural fluid cytology of the polymorphous variant of EBV-positive diffuse large B-cell lymphoma: first report and distinction from a reactive process. Case Rep Pathol. 2013. Epub 2013 Sep 3. http:// dx.doi.org/10.1155/2013/450279

15. Ridene I, Radhouani I, Ayadi A, et al. Imagerie des lymphomes pulmonaires primitifs. Rev Mal Respir. 2010;27:1069-76. PMid:21111278. http://dx.doi.org/10.1016/j.rmr.2010.09.011

16. Ooi GC, Chim CS, Lie AK, Tsang KW. Computed tomography features of primary pulmonary non-Hodgkin's lymphoma. Clin Radiol. 1999;54:438-43. http://dx.doi.org/10.1016/ S0009-9260(99)90828-0

17. Ogata-Suetsugu S, Maeyama T, Takeshita M, et al. A case of diffuse large B-cell lymphoma of the lung demonstrating diffuse ground-glass shadows. Ann Thorac cardivasc Surg. 2011;17:591-4. http://dx.doi.org/10.5761/atcs.cr.10.01651

18. Liebow AA, Carrington CRB, Friedman PJ. Lymphomatoid granulomatosis. Human Pathol.1972;3:457:558.

19. Katzenstein ALA, Doxtader E, Narendra S. Lymphomatoid granulomatosis. Insight gained over 4 decades. Am J Surg Pathol. 2010;34:e35-e48. PMid:21107080. http://dx.doi. org/10.1097/PAS.0b013e3181fd8781

20. Morice WG, Kurtin PJ, Myers JL. Expression of cytolitic lymphocyte-associated antigens in pulmonary lymphomatoid granulomatosis. Am J Clin Pathol. 2002;118:391-8. PMid:12219781. http://dx.doi.org/10.1309/PMR7-7XLYF10U-4V1Q

21. Katzenstein AL, Peiper SC. Detection of Epstein-Barr virus genomes in lymphomatoid granulomatosis: analysis of 29 cases by the polymerase chain reaction technique. Mod Pathol. 1990;3:435-41. PMid:2170969.

22. Myers JL, Kurtin PJ, Katzenstein A-LA, et al. Lymphomatoid granulomatosis. Evidence of immunophenotypic diversity and relationship to Epstein-Barr virus infection. Am J Surg Pathol. 1995;19:1300-12. PMid:7573693. http://dx.doi. org/10.1097/00000478-199511000-00011

23. Nicholson AG, Wotherspoon AC, Diss TC, et al. Lymphomatoid granulomatosis: evidence that some cases represent EpsteinBarrvirus-associated B-cell lymphoma. Histopathology.
1996;29:317-24. http://dx.doi.org/10.1111/j.1365-2559.1996. tb01415.x

24. Taniere PH, Thivolet-Bejui F, Vitrey D, et al. Lymphomatoid granulomatosis Fa report on four cases: evidence for $\mathrm{B}$ phenotype of the tumoral cells. Eur Respir J. 1998;12:102-6. http://dx.doi.org/10.1183/09031936.98.12010102

25. Guinee D Jr, Jaffe E, Kingma D, et al. Pulmonary lymphomatoid granulomatosis. Evidence for a proliferation of Epstein-Barr virus infected B-lymphocytes with a prominent T-cell component and vasculitis. Am J Surg Pathol. 1994;18:753-64. PMid:8037289. http://dx.doi. org/10.1097/00000478-199408000-00001

26. Colby TV. Current histological diagnosis of lymphomatoid granulomatosis. Mod Pathol. 2012;25:S39-42. PMid:22214969. http://dx.doi.org/10.1038/modpathol.2011.149

27. Pitaluga S, Wilson WH, Jaffe ES. Lymphomatoid granulomatosis. In: Swerdlow SH, Campo E, Harris NL, et al., editors. WHO Classification of Tumors of Haematopoietic and Lymphoid Tisssues. Lyon: ARC; 2008. p. 247-9.

28. Katzenstein AL, Carrington CB, Liebow AA. Lymphomatoid granulomatosis: a clinicopathologic study of 152 cases. Cancer.1979;43:360-73. http://dx.doi.org/10.1002/10970142(197901)43:1<360::AID-CNCR2820430151>3.0.CO;2-8

29. Bragg DG, Chor PJ, Murray KA, Kjeldsberg CR. Lymphoproliferative disorders of the lung:histopathology, clinical manifestations, and imaging features. AJR.1994;163:273-81. PMid:8037014. http://dx.doi. org/10.2214/ajr.163.2.8037014

30. Lee JS, Tuder R, Lynch DA. Lymphomatoid Granulomatosis: Radiologic features and pathologic correlations. AJR. 2000;175:1335-9. PMid:11044036. http://dx.doi.org/10.2214/ ajr.175.5.1751335

31. Chung JH, Wu CC, Gilman MD, et al. Lymphomatoid granulomatosis: CT and FDG-PET findings. Korean J Radiol. 2011;12:671-8. PMid:22043148 PMCid:PMC3194770. http:// dx.doi.org/10.3348/kjr.2011.12.6.671

32. Vahid B, Salerno DA, Marik PE. Lymphomatoid granulomatosis: a rare cause of multiple pulmonary nodules. Respir Care. 2008;53:1227-9. PMid:18718043.

33. Karabag T, Aydin M, Barut F, et al. Epicardial mass causing cardiac compression. An unusual involvement in lymphomatoid granulomatosis. Tex Heart Inst J. 2012;39:1168. PMid:22412244 PMCid:PMC3298904.

34. Zhang YX, Ding MP, Zhang T, et al. Lymphomatoid granulomatosis with CNS involvement can lead to spontaneous remission: case study. CNS Neurosci Ther. 2013;19:536-8. http://dx.doi.org/10.1111/cns.12109

35. Wilson WH, Kingma DW, Raffeld M, Wittes RE, Jaffe ES. Association of lymphomatoid granulomatosis with Epstein-Barr viral infection of B lymphocytes and response to interferonalpha 2b. Blood. 1996;87:4531-7. PMid:8639820. 
36. Makol A, Kosuri K, Tamkus D, De M Calaca W, Chang HT. Lymphomatoid granulomatosis masquerading as interstitial pneumonia in a 66-year-old man: a case report and review ofliterature. J Hematol Oncol. 2009,2:39-44. PMid:19732432 PMCid:PMC2741488. http://dx.doi.org/10.1186/1756-87222-39

37. Jordan K, Grothey A, Grothe W, Kegel T, Wolf HH, Schmoll HJ. Successful treatment of mediastinal lymphomatoid granulomatosis with rituximab monotherapy. Eur J Haematol. 2005;74:263-6. PMid:15693798. http://dx.doi.org/10.1111/ j.1600-0609.2004.00367.x
38. Aoki T, Harada Y, Matsubara E. Long-term remission after multiple relapses in an elderly patient with lymphomatoid granulomatosis after rituximab and high-dose cytarabine chemotherapy without stem-cell transplantation. J Clin Oncol. 2013; 31:e390-3. http://dx.doi.org/10.1200/JCO.2012.47.4999

39. Siegloch K, Schmitz N, Wu HS, et al. Hematopoietic stem cell transplantation in patients with lymphomatoid granulomatosis: a European group for blood and marrow transplantation report. Biol Blood Marrow Transplant. 2013;19:1522-5. PMid:23948061. http://dx.doi.org/10.1016/j.bbmt.2013.07.023

\section{Conflict of interest: None}

Submitted on: $4^{\text {th }}$ November 2013

Accept on: $5^{\text {th }}$ December 2013

Correspondence: Divisão de Clínica Médica Hospital Universitário da Universidade de São Paulo

Av. Prof. Lineu Prestes, 2565 - Cidade Universitária - São Paulo/SP - Brazil

CEP: 05508-000 - Phone: +55 (11) 3091-9200

E-mail: fpfcampos@gmail.com 